\title{
Perbandingan indeks plak gigi setelah mengunyah buah stroberi dan buah apel pada siswa SMK Negeri 6 Manado
}

\author{
${ }^{1}$ Marco S. Koagouw \\ ${ }^{2}$ Christy N. Mintjelungan \\ ${ }^{3}$ Damajanty H. C. Pangemanan
}

\author{
${ }^{1}$ Kandidat Skripsi Program Studi Pendidikan Dokter Gigi Fakultas Kedokteran \\ ${ }^{2}$ Program Studi Pendidikan Dokter Gigi Fakultas Kedokteran \\ ${ }^{3}$ Bagian Fisiologi Fakultas Kedokteran \\ Universitas Sam Ratulangi Manado \\ Email: mstevanly079@gmail.com
}

\begin{abstract}
Oral health plays an important role in human life. One effort to maintain oral health is plaque control. Plaque is a layer that is formed from food residues on the teeth that reacts with saliva, bacteria, enzymes, and acids. Strawberry and apple are juicy and fibrous fruit that are able to clean the dental plaque. This study was aimed to compare the plaque indexes after chewing strawberry and then apple. This was a quasi experimental study with a pre-post design group. This study was performed on students of 10th pharmaceutical grade SMK Negeri 6 Manado. Samples were obtained by using proportionate stratified simple random sampling of 3 classes of 10th grade. There were 55 students as respondents. The results showed that based on dental plaque index, chewing strawberries had a declined average of 0.74 meanwhile chewing apples had a declined average of 0.78 . The unpaired Ttest showed a $\mathrm{p}$ value of 0.58 ( $\mathrm{p}>0.05)$. Conclusion: Strawberries and royal gala apples could reduce dental plaque index, however, there was no significant difference between the two of them.
\end{abstract}

Keywords: munching strawberry, munching apple, plaque indeks

\begin{abstract}
Abstrak: Kesehatan gigi dan mulut merupakan hal penting dalam hidup manusia. Salah satu upaya menjaga kesehatan gigi dan mulut ialah dengan kontrol plak. Plak merupakan lapisan yang terbentuk dari sisa makanan, menempel pada gigi, dan bereaksi dengan ludah, bakteri, enzim, dan asam. Buah stroberi dan buah apel yaitu buah berair dan berserat yang mampu membersihkan plak gigi. Penelitian ini bertujuan untuk mengetahui perbandingan indeks plak setelah mengunyah buah stroberi dan apel. Jenis penelitian quasi experimental dengan rancangan pre-post design group terhadap siswa kelas X Farmasi SMK N 6 Manado. Untuk pengambilan sampel digunakan proportionate stratified simple random sampling pada 3 kelas X Farmasi dengan jumlah responden 55 siswa. Hasil penelitian menunjukkan bahwa mengunyah buah stroberi mempunyai rerata penurunan indeks plak gigi 0,74 dan mengunyah buah apel mempunyai rerata penurunan indeks plak gigi 0,78 . Uji $\mathrm{T}$ tidak berpasangan menunjukkan nilai $p=0,58(p>0,05)$. Simpulan: Buah stroberi dan buah apel royal gala dapat menurunkan nilai indeks plak gigi tetapi tidak terdapat perbedaan bermakna antara keduanya.
\end{abstract}

Kata kunci: mengunyah, buah stroberi, buah apel, plak gigi

Kesehatan merupakan bagian terpenting dalam hidup manusia. Seseorang dikatakan sehat tidak hanya dari tubuhnya saja tetapi sehat juga di dalam rongga mulut dan gigi. Menjaga kesehatan gigi dan mulut seseorang dapat terhindar dari karies dan 
penyakit periodontal. Karies dan penyakit periondontal masih menjadi masalah yang serius dalam kesehatan gigi dan mulut terlebih khusus pada anak muda di Indonesia. ${ }^{1}$ Hasil dari Riset Kesehatan Dasar (RISKESDAS) tahun 2013, menyatakan bahwa dominasi terbesar dalam masalah kesehatan gigi dan mulut pada masyarakat sebesar $25,9 \%$ dan provinsi Sulawesi Utara termasuk dalam prevalensi buruknya masalah kesehatan gigi dan mulut yaitu mencapai $31,6 \%$ bermasalah gigi dan mulut. ${ }^{2}$ Kebersihan rongga mulut dapat dilihat dengan ada tidaknya deposit organik, seperti sisa makanan, pelikel, kalkulus, dan plak gigi.

Plak merupakan lapisan yang terbentuk dari sisa makanan yang menempel pada gigi yang bereaksi dengan ludah, bakteri, enzim dan asam. Lengketan berisi bakteri yang terbentuk pada permukaan gigi dan plak terjadi ketika makan yang mengandung karbohidrat, minuman ringan, kue atau permen dan tersisa pada gigi. Pembersihan gigi yang kurang baik menyebabkan plak semakin melekat. ${ }^{3,4}$

Plak dapat dihilangkan dengan kontrol plak yang terdiri atas tiga cara yaitu: mekanik, kimiawi, dan alamiah. Cara mekanik bisa dilakukan dengan menggosok gigi sedangkan cara kimia dapat dilakukan dengan berkumur memakai obat anti bakteri. Cara menggosok gigi lebih efektif dalam menurunkan plak apalagi dengan menggosok gigi secara teratur. ${ }^{5}$ Mengunyah buah yang segar, berserat, dan berair dapat juga membantu membersihkan rongga mulut, terlebih merangsang sekresi saliva yang berguna melindungi gigi. ${ }^{6}$

Buah stroberi dan buah apel yaitu buah berair dan berserat yang mampu membersihkan plak gigi. Zat yang terkandung didalam buah stroberi yaitu salicylic acid, ellagic acid, katekin, dan antosianin mampu mengurangi pembentukan plak. $^{7}$ Buah apel juga mempunyai senyawa konsentrasi tinggi yaitu tannin yang dapat mencegah kerusakan pada gigi dan penyakit gusi yang disebabkan oleh tumpukan plak. ${ }^{8}$ Menurut Mukti $^{5}$ mengunyah buah stroberi secara mekanik dengan cara mengunyah 32 kali pada sisi rahang kanan dan kiri dapat menghambat dan menurunkan indeks plak. Penda et al. ${ }^{9}$ melaporkan bahwa dengan mengunyah buah apel 32 kali pada sisi rahang kanan dan kiri dapat mengontrol dan menurunkan indeks plak. Mengunyah buah stroberi dan apel dapat efektif menjaga kesehatan gigi dan mulut agar tetap sehat dan bersih dengan cara alami.

Penelitian ini bertujuan untuk membandingkan indeks plak gigi setelah mengunyah buah stroberi dan buah apel pada siswa SMK Negeri 6 Manado. Penulis memilih Sekolah Menengah karena pada Data Riset Kesehatan Dasar Tahun 2013 usia tersebut mempunyai masalah gigi dan mulut yang cukup tinggi. Berdasarkan survei awal di sekolah tersebut berbasis kesehatan dan juga belum pernah dilakukan penelitian tentang kebersihan gigi dan mulut. Umumnya siswa lebih menyukai makanan cepat saji tanpa mengetahui manfaat dari buah-buahan dalam menjaga kesehatan gigi dan mulut. Selain itu juga di SMK Negeri 6 Manado belum tersedia Usaha Kesehatan Gigi Sekolah (UKGS), oleh karena itu penulis ingin memperkenalkan manfaat buah dalam menjaga kesehatan gigi dan mulut, terlebih khusus pada buah stroberi dan apel dalam menurunkan indeks plak.

\section{BAHAN DAN METODE PENELITIAN}

Jenis penelitian ini ialah quasi experimental dengan rancangan pre-post design group. Penelitian ini dilaksanakan di SMK Negeri 6 Manado pada bulan JuniAgustus 2016. Populasi penelitian ini ialah siswa kelas X jurusan Farmasi SMK Negeri 6 Manado yang berjumlah 118 siswa. Pengambilan sampel dengan cara proporsional (proportionate stratified simple random sampling) yang sesuai dengan kriteria inklusi dan eksklusi. Jumlah sampel diperoleh dengan menggunakan rumus Slovin sebanyak 55 sampel.

Prosedur pemeriksaan responden ialah terlebih dahulu diolesi disclosing solution pada permukaan gigi yang diperiksa dengan menggunakan cotton pellet 
kemudian diperiksa indeks plak pada 6 segmen gigi yang telah diolesi disclosing solution. Perlakuan pertama responden diberi buah stroberi sebesar 50 gram untuk dikunyah sebanyak 32 kali yaitu sisi rahang kanan 16 kali pengunyahan dan sisi rahang kiri 16 kali pengunyahan kemudian dilakukan pemeriksaan indeks plak dengan menggunakan disclosing solution, dan dicatat skor indeks plak akhir. Langkah yang sama juga dilakukan pada pengunyahan buah apel royal gala dengan 55 sampel tersebut setelah 3 hari perlakuan pertama. Analisis data menggunakan uji normalitas Kolmogorov-Smirnov, uji paired T-test dan uji Independent T-test.

\section{HASIL PENELITIAN}

Responden penelitian ini yaitu siswa SMK Negeri 6 Manado kelas X jurusan Farmasi berdasarkan kriteria inklusi dan eksklusi sebanyak 55 siswa. Tabel 1 menunjukkan responden penelitian berjenis kelamin laki-laki sebanyak 17 siswa dan responden penelitian berjenis kelamin perempuan sebanyak 38 siswa yang diperoleh secara random di masing-masing kelas.

Tabel 1. Karakteristik responden berdasarkan jenis kelamin

\begin{tabular}{ccc}
\hline Jenis kelamin & n & \% \\
\hline Laki-laki & 17 & 30,9 \\
Perempuan & 38 & 69,1 \\
Total & 55 & 100 \\
\hline
\end{tabular}

Hasil pemeriksaan kategori indeks plak pada siswa farmasi kelas $\mathrm{X}$ dengan perlakuan mengunyah buah stroberi dinilai dari sebelum mengunyah dan sesudah mengunyah buah stroberi (Tabel 2). Hasil pemeriksaan indeks plak sebelum mengunyah buah stroberi menunjukkan tidak terdapat responden yang tergolong kategori indeks plak sangat baik dan baik; 27 siswa tergolong kategori sedang; dan 28 siswa tergolong kategori buruk. Indeks plak sesudah mengunyah buah stroberi 50 gram menunjukkan tidak terdapat responden dengan kategori buruk dan sangat baik; 19 siswa tergolong pada kategori baik; dan 36 siswa tergolong kategori sedang.

Tabel 2. Distribusi kategori indeks plak pada responden yang mengunyah buah stroberi

\begin{tabular}{ccccc}
\hline Indeks & \multicolumn{2}{c}{ Sebelum } & \multicolumn{2}{c}{ Sesudah } \\
\cline { 2 - 5 } plak gigi & $\mathrm{n}$ & $\%$ & $\mathrm{n}$ & $\%$ \\
\hline Sangat baik & 0 & 0 & 0 & 0 \\
Baik & 0 & 0 & 19 & 34,5 \\
Sedang & 27 & 49,1 & 36 & 65,5 \\
Buruk & 28 & 50,9 & 0 & 0 \\
Total & 55 & 100 & 55 & 100 \\
\hline
\end{tabular}

Tabel 3 menunjukkan pada hasil pemeriksaan indeks plak sebelum mengunyah buah apel tidak terdapat sampel yang tergolong kategori indeks plak sangat baik dan baik; 24 siswa tergolong kategori sedang; dan 31 siswa tergolong kategori buruk. Indeks plak sesudah mengunyah buah apel menunjukkan tidak terdapat responden dengan kategori sangat baik, sebanyak 18 siswa dengan kategori baik, untuk kategori sedang terdapat 36 siswa, sedangkan ada juga 1 siswa yang tergolong kategori indeks plak buruk.

Tabel. 3. Distribusi kategori indeks plak pada responden yang mengunyah buah apel royal gala

\begin{tabular}{ccccc}
\hline Indeks & \multicolumn{2}{c}{ Sebelum } & \multicolumn{2}{c}{ Sesudah } \\
\cline { 2 - 5 } plak gigi & $\mathrm{n}$ & $\%$ & $\mathrm{n}$ & $\%$ \\
\hline Sangat baik & 0 & 0 & 0 & 0 \\
Baik & 0 & 0 & 18 & 32,7 \\
Sedang & 24 & 43,6 & 36 & 65,5 \\
Buruk & 31 & 56,4 & 1 & 1,8 \\
Total & 55 & 100 & 55 & 100 \\
\hline
\end{tabular}

Tabel 4 menunjukkan uji KolmogorovSmirnov pada perlakuan sebelum mengunyah buah Stroberi $(p=0,77)$ dan sesudah mengunyah buah stoberi $(p=1,09)$ yang menunjukkan data terdistribusi normal.

Tabel 5 menunjukkan uji KolmogorovSmirnov pada perlakuan sebelum mengunyah buah apel royal gala $(p=0,77)$ dan sesudah mengunyah buah apel $(p=$ 1,05) yang menunjukkan data terdistribusi normal. 
Tabel 6 menunjukkan terdapat perbedaan penurunan indeks plak antara sebelum dan sesudah mengunyah buah stroberi, dimana rata-tata indeks plak sebelum mengunyah 1,92 dan sesudah mengunyah buah stroberi 1,18 dengan selisih rata-rata 0,74 . Hasil analisis menunjukkan adanya penurunan signifikan antara sebelum dan sesudah mengunyah buah stroberi $(\mathrm{p}=$ $0,00)$.

Tabel 7 menunjukkan terdapat perbedaan indeks plak antara sebelum dan sesudah mengunyah buah stroberi, di mana nilai rata-rata indeks plak sebelum mengunyah 2,00 dan sesudah mengunyah 1,22 dengfan selisih rata-rata 0,78 . Hasil analisis menunjukkan adanya penurunan bermakna sebelum dan sesudah mengunyah buah apel royal gala $(\mathrm{p}=0,00)$.

Hasil uji Independent T-test (Tabel 8) menunjukkan tidak terdapat perbedaan bermakna setelah mengunyah buah stroberi dan buah apel royal gala $(\mathrm{p}=0,58)$.

Tabel 4. Uji normalitas Kolmogorov-Smirnov buah stroberi

\begin{tabular}{|c|c|c|c|c|c|}
\hline & Perlakuan & Mean & Std Deviation & $\begin{array}{l}\text { Kolmogorov- } \\
\text { Smirnov }\end{array}$ & $\mathbf{n}$ \\
\hline \multirow{2}{*}{ Hasil } & Sebelum & 1,92 & 0,31 & 0,77 & 55 \\
\hline & Sesudah & 1,18 & 0,33 & 1,09 & 55 \\
\hline
\end{tabular}

Tabel 5. Normalitas Kolmogorov-Smirnov buah apel royal gala

\begin{tabular}{cccccc}
\hline & Perlakuan & Mean & Std Deviation & $\begin{array}{c}\text { Kolmogorov - } \\
\text { Smirnov }\end{array}$ & n \\
\cline { 2 - 6 } Hasil & Sebelum & 2,00 & 0,34 & 0,77 & 55 \\
& Sesudah & 1,22 & 0,35 & 1,05 & 55 \\
\hline
\end{tabular}

Tabel 6. Uji paired T-test mengunyah buah stroberi

\begin{tabular}{ccccccc}
\hline Mengunyah stroberi & n & Mean & Std. Deviation & Mean selisih & Df & Sig. \\
\hline Sebelum & 55 & 1,92 & 0,31 & \multirow{2}{*}{0,74} & \multirow{2}{*}{54} & \multirow{2}{*}{0,00} \\
Sesudah & 55 & 1,18 & 0,33 & &
\end{tabular}

Tabel 7. Uji paired T-test mengunyah buah apel royal gala

\begin{tabular}{ccccccc}
\hline Mengunyah apel & n & Mean & Std. Deviation & Mean selisih & Df & Sig. \\
\hline Sebelum & 55 & 2,00 & 0,34 & 0,78 & \multirow{2}{*}{54} & 0,00 \\
Sesudah & 55 & 1,22 & 0,35 & & &
\end{tabular}

Tabel 8. Uji independent T-test sesudah mengunyah buah stroberi dan apel royal gala.

\begin{tabular}{ccccccc}
\hline Mengunyah buah & n & Mean & Std. Deviation & Mean selisih & Df & Sig. (2-tailed) \\
\hline Stroberi & 55 & 1,18 & 0,33 & 0,036 & \multirow{2}{*}{108} & 0,58 \\
Apel & 55 & 1,22 & 0,35 & & \\
\hline
\end{tabular}

\section{BAHASAN}

Data karakteristik responden penelitian mendapatkan jenis kelamin perempuan lebih banyak $(69,1 \%)$ dibandingkan lakilaki $(30,9 \%)$. Karakteristik responden penelitian berdasarkan usia mendapatkan usia 13 hingga 14 tahun lebih dominan.
Pada penelitian ini digunakan buah stroberi seberat 50 gram dan buah apel royal gala seberat 50 gram pada siswa SMK N 6 Manado diberikan satu kali kepada responden untuk dikunyah. Buah stroberi dan apel merupakan makanan yang bersifat tidak merangsang pembentukan 
plak melainkan sebagai pengendali plak alami atau sebagai pembersih alami pada permukaan gigi. Pembersihan alami membantu menyingkirkan partikel-partikel makanan dan gula selama proses pengunyahan. ${ }^{10}$ Proses pengunyahan dibantu oleh otot-otot pengunyahan, sebelum menelan bila dilakukan dengan baik membantu pemeli-haraan kesehatan rongga mulut dimana otot bertanggung jawab membantu gigi geligi beroklusi yang normal. ${ }^{11}$

Uji normalitas Kolmogorov-Smirnov, nilai $\mathrm{p}$ sebelum mengunyah buah stroberi sebesar 0,77 dan sesudah mengunyah buah stroberi 1,09. Pada uji normalitas Kolmogorov-Smirnov mengunyah buah apel royal gala sebelum sebesar 0,77 dan sesudah sebesar 1,05. Hasil tersebut menunjukkan bahwa data tersebut terdistribusi dengan normal.

Untuk mengetahui perbedaan sebelum dan sesudah mengunyah buah stroberi dan buah apel dipakai uji paired T-test. Nilai $\mathrm{p}$ sebelum dan sesudah mengunyah buah stroberi dan buah apel royal gala sebesar 0,00 yang menunjukkan terdapat perbedaan bermakna antara sebelum dan sesudah mengunyah $(\mathrm{p}<0,05)$.

Hasil penelitian ini sejalan dengan penelitian yang dilakukan oleh $\mathrm{Mukti}^{5}$ pada anak remaja usia 12-18 tahun di Panti Asuhan Yayasan Nur Hidayah Surakarta, yang mendapatkan sebelum dan sesudah mengunyah buah stroberi mempunyai perbedaan bermakna dalam menurunkan indeks plak. Pada penelitian ini didapatkan bahwa dengan mengunyah terdapat penurunan indeks plak sesudah mengunyah buah stroberi dan dapat menghambat pertumbuhan jumlah plak gigi. Penelitian yang dilakukan oleh Godried ${ }^{7}$ mendapatkan bahwa jus stroberi berefek anti bakteri yang bermakna terhadap Streptococcus mutans. Penelitian tersebut menyimpulkan bahwa buah stroberi terbukti baik untuk menurunkan indeks plak karena adanya kandungan bahan-bahan aktif seperti salicilic acid, ellagic acid, katekin, dan antosianin.

Penelitian oleh Taufik et al. ${ }^{12}$ menggunakan buah apel terhadap anakanak berusia 9-14 tahun di Panti Asuhan Taman Harapan Muhammadiyah Bandung mendapatkan bahwa indeks plak menurun setelah mengunyah apel terutama pada daerah oklusal gigi posterior. Penelitian yang sama juga dilakukan pada 44 siswa SMA Negeri 1 Sorong Barat oleh Penda et al. ${ }^{9}$ tahun 2015 dengan metode pra eksperimental dan rancangan pretest and posttest one group only. Hasil penelitian menunjukkan rerata indeks plak sebelum pengunyahan buah apel ialah 2,1 dan rerata setelah pengunyahan buah apel ialah 1,2. Terdapat perbedaan bermakna sebelum dan sesudah mengunyah buah apel. ${ }^{9}$

Mengunyah buah stroberi dan buah apel royal gala dapat menurunkan indeks plak gigi. Pada uji Independent T-test didapatkan rerata indeks plak setelah mengunyah buah stroberi sebesar 1,18 dan setelah mengunyah buah apel sebesar 1,22. Selisih indeks plak sebelum dan sesudah mengunyah buah stroberi yaitu sebesar 0,74 dan pada buah apel royal gala sebesar 0,78 .

Hasil penelitian ini mendapatkan bahwa kedua buah tersebut mempunyai efek kontrol plak yang dipengaruhi oleh air dan serat yaitu ketika buah masuk kedalam rongga mulut dan dikunyah terjadi sekresi saliva yang merupakan suatu tindakan mekanis yang dapat menghambat kolonisasi bakteri pada permukaan gigi, menghalangi pembentukan plak, mencegah mineralisasi, serta melarutkan plak yang sudah terbentuk sehingga terjadi penurunan indeks plak gigi. Hasil tersebut didukung oleh penelitian Noviana ${ }^{13}$ yang dilakukan dengan pemberian jus apel dan jus stroberi pada siswa anak SDN Cibogo Bandung yang menyatakan bahwa kedua buah tersebut mempunyai penurunan indeks plak yaitu stroberi $14,3 \%$ dan apel $50,8 \%$ pada uji perbandingan. Simpulan dari penelitian tersebut yaitu jus buah stroberi lebih bermakna dari jus buah apel dalam penurunan indeks plak.

Secara kimiawi buah stroberi banyak mengandung zat yang bermanfaat untuk kesehatan, antara lain flavonoid, asam 
malat, vitamin A, C, E, elagic acid, zat besi, asam folat, dan serat. ${ }^{14}$ Flavonoid merupakan sekelompok besar sebagai antioksidan bernama polifenol. Polifenol yang terkandung dalam stroberi ialah asam elagik, antosianin, dan katekin. Katekin pada stroberi termasuk golongan terbesar polifenol yang mempunyai mekanisme kerja menghambat pertumbuhan bakteri dengan cara inaktivasi protein pada membran sel sehingga struktur protein rusak. ${ }^{5,14,15}$ Stroberi juga mempunyai zat yang dapat mencegah terjadinya karies gigi. ${ }^{16}$

Buah apel mempunyai zat aktif yang dapat menghambat pertumbuhan bakteri dalam rongga mulut melalui reaksi biokimiawi yang diperankan oleh katekin. ${ }^{17}$ Selain katekin terdapat juga tanin yaitu senyawa polifenol dengan konsentrasi tinggi yang dapat mencegah kerusakan gigi dan penyakit gingiva yang disebabkan oleh penumpukan plak. ${ }^{9}$ Mekanisme tanin dan katekin menghambat pembentukan plak gigi dengan cara menghambat reaksi pembentukan glikosilasi, menghambat perlekatan bakteri Streptococcus mutans pada permukaan gigi, dan mendenaturasi protein sel bakteri sehingga bakteri Streptococcus mutans mati. ${ }^{5,9,18}$

\section{SIMPULAN}

Berdasarkan hasil penelitian pada siswa SMK N 6 Manado kelas X Farmasi dapat disimpulkan bahwa mengunyah buah stroberi dan buah apel dapat menurunkan indeks plak gigi tetapi tidak terdapat perbedaan bermakna pada indeks plak gigi setelah mengunyah kedua buah tersebut.

\section{SARAN}

1. Perlu adanya penelitian lebih lanjut mengenai mengunyah buah secara bervariasi dengan responden yang berbeda dalam menentukan penurunan indeks plak gigi.

2. Perlu adanya penelitian lebih lanjut dengan metode eksperimen laboratorium dengan ekstrak buah stroberi dan ekstrak buah apel terhadap berbagai bakteri penyebab kerusakan gigi.
3. Diharapkan untuk mengonsumsi buah stroberi dan buah apel yang bermanfaat membersihkan rongga mulut terlebih lagi menghambat dan menurunkan indeks plak gigi.

\section{DAFTAR PUSTAKA}

1. Pitauli S, Hamada T. Menuju Gigi dan Mulut Sehat: pencegahan dan pemeliharaan. Medan: USU press, 2008; p. 4.

2. Departemen kesehatan Republik Indonesia. Laporan hasil riset kesehatan dasar (riskesdas) nasional 2013. Jakarta: Kementerian Kesehatan RI, 2013.

3. Sariningsih E. Gigi Busuk dan Poket Periodontal sebagai Fokus Infeksi. Jakarta: PT Elex Media Komputindo, 2014; p. 253.

4. Putti FD, Restadiamawati. Pengaruh konsumsi permen karet yang mengandung xylitol terhadap pembentukan plak gigi [Karya tulis ilmiah]. Semarang: Universitas Diponogoro; 2015.

5. Mukti NAK. Pengaruh mengunyah buah stroberi terhadap hambatan pembentukan plak gigi pada anak remaja 12-18 tahun di panti asuhan Yayasan Nurhidayah Kota Surakarta [Naskah publikasi]. Surakarta: FKG Universitas Muhammadiyah; 2014.

6. Haida KE, Cholil, Aspriyanto D. Perbandingan efektivitas mengunyah buah pir dan bengkuang terhadap penurunan indeks plak. Dentino. 2007;II(1):24-5.

7. Godfied YE. Perbandingan efek anti bakteri jus stroberi (Fragaria vesca L) pada berbagai konsentrasi terhadap Streptococcus mutans [Karya tulis ilmiah]. Semarang: Universitas Diponegoro; 2007.

8. Ramdhani RA. Efektivitas mengunyah buah apel (Pyrus malus) dan buah pir (Pyrus communis $L$ ) terhadap penurunan plak [Karya tulis ilmiah]. Yogyakarta: Fakultas Kedokteran UMY; 2012.

9. Penda PAC, Kaligis SHM, Juliatri. Perbedaan indeks plak sebelum dan sesudah mengunyah buah apel. e-G. 2015;3(2):380-6.

10. Eka C, Eriska R, Feny F. Perbedaan tingkat kebersihan gigi dan mulut antara anak vegetarian dan non vegetarian di Vihara 
Maitreya Pusat Jakarta. Jurnal Kedokteran Gigi Indonesia Edisi Khusus PIN IKGA II. 2007:79-84.

11. Andriyani A. Aspek fisiologis pengunyahan dan penelanan pada sistem stomatognasi [Skripsi]. Medan: Universitas Sumatra Utara; 2001.

12. Taufik F, Riyanti R, Hadidjah D. Index plaque differences between before and after chewing apples. Available from: repository.unpad.ac.id.

13. Noviana T. Perbedaan efektivitas pemberian jus apel (Pyrus Malus) atau jus stroberi (Fragaria Chiloensis L) untuk menghambat akumulasi plak gigi pada anak Cibogo Bandung [Skripsi]. Semarang: Universitas Diponegoro; 2009.

14. Lestari P, Maharani ES. Efektifitas ekstrak stroberi (Fragaria $x$ ananassa) terhadap penurunan plak gigi [Karya tulis ilmiah]. Yogyakarta: Program Studi Pendidikan Dokter Gigi Fakultas
Kedokteran dan Ilmu Kesehatan Universitas Muhammadiyah; 2015.

15. Santoso R. Daya anti bakteri ektrak daun pare (Momordica charantia) dalam menghambat pertumbuhan Streptococcus viridans [Artikel ilmiah]. Jember: Universitas Jember; 2012.

16. Kusumaningsih W. Pengaruh pasta gigi dengan kandungan buah stroberi (fragaria chiloensis L) terhadap pembentukan plak gigi [Karya tulis ilmiah]. Semarang: FKU Diponegoro; 2011.

17. Dewi RAP. Pengaruh pasta gigi dengan kandungan buah apel (Pyrus malus) terhadap pembentukan plak gigi [Artikel ilmiah]. Semarang: FK Diponegoro; 2011.

18. Mailoa M, Mahendradatta M, Laga A, Djide N. Animicrobial activities of tannis extract from guava leaves (Psidium Guajava L) on phatogens microbial. IJSTR. 2014;3(1):236-41. 